\title{
Intersecting and Contrasting Lives: G.M. Trevelyan and Lytton Strachey
}

\section{Alastair MacLachlan}

This essay is about history and biography in two senses. First, it examines two parallel and intersecting, but contrasting lives: that of George Macaulay Trevelyan (b. 1876), probably the most popular historian and political biographer of early twentieth-century England - a Fellow and in old age the Master of Trinity College, Cambridge, an independent scholar for 25 years and, for 12 years, Regius Professor of Modern History and that of his slightly younger Trinity protégé, Giles Lytton Strachey (b. 1880), a would-be academic rejected by the academy, who set himself up as a critical essayist and a historical gadfly - the writer credited with the transformation of a moribund genre of pious memorialisation into a 'new' style of biography. Second, the essay explores their approaches to writing nineteenth-century history and biography, and it assesses their works as products of similar but changing times and places: Cambridge and London from about 1900 to the 1930s. ${ }^{1}$ 
'Read no history', advised Disraeli, 'nothing but biography, for that is life without theory'. But 'life without theory' can be intellectually emaciated, and a comparative biography may have the advantage of kneading into the subject theoretical muscle sometimes absent in single lives, highlighting the points where the two lives intersected and what was common and what distinctive about them. As such, it may limit what Terry Eagleton called 'the remorseless linearity and covert anti-intellectualism of the biographical form', and may provide some of the broader contexts Trevelyan found through an engagement with geography and history, and some of the clarity and coherence Strachey sought through 'the new biography'. ${ }^{2}$

The two men had much in common. Born within four years of each other, they belonged to the late Victorian intellectual aristocracy. They shared common Whig ancestries, home lives steeped in literature and history, and curiously coincident but contrasting Anglo-Indian backgrounds. Both were residual, godless products of the early nineteenth-century evangelical movement. At Cambridge, they were scholars of Trinity College, graduates of the tiny as yet unnamed History Faculty, and defenders of the belletristic tradition of historical writing against the new gospel of scientific history proclaimed by Professor J.B. Bury in a famous inaugural of 1903 . Above all, they both were members of the elite 'Cambridge Apostles': a society with a distinctive collective identity at the turn of the twentieth century, marked by intense devotion to the ethical and philosophical values formulated by G.E. Moore, shared by their friends, 'Goldie' Dickinson, Bertrand Russell, Leonard Woolf and Maynard Keynes, and subsequently embraced by 'Bloomsbury'.

A comparative study, however, needs to address difference as well as similarity, and I shall also suggest divergences of nature and nurture, which helped to shape their distinctive styles of living, thinking and writing. Some were perhaps biologically or at least sexually determined; some went back to the distinctive features of their homes, families and early educational experiences. Others were developed in Cambridge, where despite close elective affinities, there were acute tensions between the two men, articulated in radically dissimilar ideals of 'reality' and

2 Benjamin Disraeli, Contarini Fleming (New York: Harper, 1832), Part 1, ch. 23; Ray Monk, 'Life without Theory: Biography as an Exemplar of Philosophical Understanding', Poetics Today, 28:3 (2007), 527-70, doi.org/10.1215/03335372-2007-007; Terry Eagleton, 'First Class Fellow Traveller', review of Patrick Hamilton: A Life by Sean French, London Review of Books (LRB), 15:23, 2 December 1993. 
'phenomena', goodness and the proper ends of life. Some of these tensions focused on their 'Apostolic' characters and their relationship with Moore, while others were the products of constructed identities: the increasingly different personae they forged for themselves in the decades before, during and after the First World War.

These temperamental differences resulted in two very different 'archives'. Shortly before he died, Trevelyan burned virtually all his personal papers. He could not, of course, destroy what he had written to other people. Genuinely self-effacing and incurious about himself, he never in his opinion 'wrote a private letter worth printing'. He did not keep a diary; his sex life was unrecorded and unremarkable. On the other hand, in the period up to the First World War, he aspired to the role of a public man of letters, and he viewed his writings not as disinterested research, but as 'Tracts for the times'. Before, during and after the war, he was a committed internationalist, an active conservationist and a recreational champion. So his life is imbedded in the history of English politics and society to a degree unusual in a conventional academic historian. ${ }^{3}$

Strachey kept virtually all his papers. Unlike Trevelyan, he was immensely curious about himself: 'I am an egoist', he told his sister, and everything he wrote - biographies, literary essays, plays, dialogues, poems - bore the imprint of his idiosyncratic personality. He was an inveterate gossip and a prolific, candid letter writer; his personal archive consisted ultimately of over 30,000 items stored in boxes, trunks and suitcases. Unlike Trevelyan, Strachey was an aesthete and intellectual mandarin: public life repelled him. He shrank from contact with what he called 'the phenomenal world' - a world, as he saw it, marked by 'stupidity, vulgarity and falseness'. Like many chronically sick people, he found it hard to cope with healthy, boisterous, interfering people like Trevelyan. If, as Leonard Woolf claimed, he was 'keenly interested' in politics, he was also acutely aware of the costs of social activism. Though public affairs impinged on his life more than he recognised, notably during the First World War, what he really valued

3 G.M. Trevelyan, An Autobiography and Other Essays (London: Longmans, Green, 1949), 1-2; GMT to Robert Calverley Trevelyan, 20 May 1949, in Peter Raina, George Macaulay Trevelyan: A Portrait in Letters (Edinburgh: Pentland, 2001), 154; David Cannadine, G. M. Trevelyan: A Life in History (London: HarperCollins, 1992), xiv, 1-55. 
was literature, music, art and talk. His ethic was one of beauty, truth and friendship, focused on 'good states of mind' rather than on public duty and good conduct. ${ }^{4}$

Thus, increasingly, Strachey scorned the civic sermons and literary pretentions of would-be mentors like Trevelyan and, since he could be witheringly dismissive, there is much comedy in their mésalliance. ${ }^{5}$ To some degree, this then is a study in contrasts. Trevelyan had a career; Strachey a life. 'Trevy', as he was known to friends, found fulfilment outside writing in a wide range of political, social, international and institutional activities; Strachey found his in conversation, correspondence and personal relationships.

In August 1918, the 42-year-old Trevelyan - author of three reverential biographies of nineteenth-century liberal heroes: Garibaldi, John Bright and Grey of the Reform Bill - was sitting in a railway carriage in northern Italy, on his way home from front-line duties. On his lap was an exceedingly unreverential study of four nineteenth-century lives, Eminent Victorians, by Lytton Strachey. The train was slow, and he was able to finish it at 'one long sitting,' he told Lytton, 'with the most intense pleasure, approval and admiration'. He congratulated Strachey on his 'judgement' and 'historical sense', and concluded in his most avuncular manner: 'you have found a method of writing about history which suits you admirably, and I hope you will pursue it'. In Brixton Prison, another 'Angel' or ex-Apostle', the philosopher Bertie Russell, was chortling over Lytton's pages, only to be told by a warder that incarceration for wartime sedition was no laughing matter. Second thoughts convinced Trevy that Eminent Victorians was no laughing matter either. ${ }^{6}$

Why Trevelyan came to deplore Strachey's biographical style can partly be explained by homes and families. In an essay read to the Bloomsbury 'Memoir Club' in 1922, Strachey remarked that 'the influence of houses

4 S to D. Bussy, 8 January 1908, Robert Taylor Mss, Princeton, Box 18/12; Leonard Woolf, review of Lytton Strachey, Vol 1: The Unknown Years, 1880-1910 by Michael Holroyd, New Statesman (NS), 26 November 1965.

5 S to L. Woolf, 24 February 1905, Harry Ransome Humanities Research Center, University of Texas at Austin (HRHC), Strachey Mss, Box 4, folder 4; 'Shall We Go the Whole Hog?', Paper to the Cambridge Apostles, 25 February 1905, British Library (BL) Strachey Mss, Additional Mss (Add. Ms.), 81,890; Todd Avery, ed., The Works of Lytton Strachey: Early Papers (London: Pickering Masters, 2011), 99-104.

6 T to S, 12 August 1918, BL, Add.Ms., 60,732, ff. 195-6; Bertrand Russell, The Autobiography of Bertrand Russell (3 vols; London: Allen \& Unwin, 1951-69), vol. 1, 34; Michael Holroyd, Lytton Strachey: The New Biography (LSNB) (London: Chatto \& Windus, 1994), 427. 
on their inhabitants might well be the subject of a scientific investigation'. And he explored the atmospherics of place and the formation of personality in his own case at 69 Lancaster Gate, the huge Victorian terrace, where he grew up. 'To reconstruct that grim machine', he suggested, 'would be to realize with ... real distinctness the essence of my biography.' It was a building where 'size (had) gone wrong' and had become 'pathological'. At once too large with seven floors and half-landings it was also pokey, dowdy and rundown. There were times when he and his sisters wondered if it was 'one vast "filth packet," and we the mere disjecta membra of vanished generations'. Yet alongside Dickensian decomposition, went a Victorian assurance and stability that came from the house as 'an imperturbable mass - the framework, almost the very essence - so it seemed - of our being'.

Trevelyan's formative experiences, in some respects curiously similar, in their setting and ambience were very different. He grew up largely at Wallington, the family home on the edge of the Northumbrian moors. Built 'on the model of great French chateau', Wallington is stately, commodious, compact. Begun in 1688, the red-letter year of aristocratic liberation, by the mid-eighteenth century it had become a quintessentially Whig home, improved in fashionable Palladian style. It was crowned in the nineteenth century, by the creation of a great central saloon - 'one of the most remarkable rooms in any English country house', its balustrades decorated by the family's Pre-Raphaelite friends with 'portrait medallions of famous Northumbrians, culminating in the mid-nineteenth-century Trevelyans'. Like the drawing-room at Lancaster Gate, it was 'a temple erected to the spirit of Victorianism'. But the Trevelyans loved it. Trevy's father, George Otto, thought it the finest room in England. In the writing room stood the desk where Trevy's great-uncle, Thomas Macaulay, wrote his History of England; in the study, the table on which his father completed his Life and Letters of Lord Macaulay two weeks before Trevy's birth. Little wonder Trevy was convinced at the age of 18 that history would be his 'task in life', and that he wrote as if before 'a bust of Lord Macaulay'. ${ }^{8}$

7 Lytton Strachey, 'Lancaster Gate', in Michael Holroyd, ed., Lytton Strachey by Himself: A SelfPortrait (London: Heinemann, 1971), 16-28; S.P. Rosenbaum, The Bloomsbury Group Memoir Club (Basingstoke: Palgrave Macmillan, 2014), 110-12.

8 George Otto Trevelyan, 'Wallington', Country Life, 53 (1918), 22, 29 June 1918; R. Trevelyan, Wallington, The National Trust (London: The National Trust, 1994), 56-63; Stefan Collini, 'Like Family, like Nation', review of G.M. Trevelyan: A Life in History by David Cannadine, Times Literary Supplement (TLS), 16 October 1992, 3-4; Collini, English Pasts (Oxford: Oxford University Press, 1999), 10; John Batchelor, Lady Trevelyan and the Pre-Raphaelite Brotherhood (London: Chatto $\&$ Windus, 2006); Cannadine, Trevelyan, 11, 28. 
Like many elite British families, the Trevelyans cared as much for the rural surrounds as for bricks and mortar. Although he lived much of his life in urban settings, Trevelyan thought of himself as a countryman. He was one of those late Victorian 'pilgrims of scenery', for whom 'landscape theology' served as a substitute religion. So, when he thought of Wallington, he thought immediately of the gardens, park and the estate, as it eased out to the 'moors and sheep runs that sweep up to the Scottish border', which he evoked in some of his best early essays. So home and nature coalesced: if Lancaster Gate for Strachey connoted rupture, disintegration, 'degringolade', here was repose, fusion, seamless continuity.'

The Stracheys were an old, West Country gentry family and, according to their most recent biographer, were 'extremely conscious of their heritage and of their extensive familial connections'. To an outsider such as Leonard Woolf, 'the atmosphere of the dining room at Lancaster Gate was that of British history and of the comparatively small ruling middle class which for the last hundred years had been [its] principal makers'. ${ }^{10}$ Lytton's oldest uncle, Sir Edward, lived in Sutton Court, the ancestral home at Stowey in Somerset - a largish fifteenth-century country house, greatly extended in Elizabethan times by the formidable Bess of Hardwick. Though modest by the standards of Bess's other homes, it reminded Lytton that his 'father and mother belonged by birth and breeding to the old English world of country-house gentlefolk'. But it also ironically highlighted the gap between their straightened material circumstances and the 'secure world of dynastic strength, piety and imperial power' whence they came. ${ }^{11}$

For the Stracheys were a large, long-lived dynasty - 10 or more children were common, and all five of Lytton's uncles lived into their 80 s - so that his father, Richard, a third son, had to make his own way in the world. The same was true of his mother's immediate family, the Grants

9 Collini, 'Like Family, like Nation'; T to G.O. Trevelyan, 2 June 1918, Philip Robinson Library, University of Newcastle (PRL), Trevelyan Mss, GOT 94; G.M. Trevelyan, 'The Middle Marches', Independent Review (IR), 5 (1905), 231-40; Trevelyan, Clio, a Muse, and Other Essays Literary and Pedestrian (London: Longmans, Green, 1913), 56-81.

10 Barbara Caine, Bombay to Bloomsbury: A Biography of the Strachey Family (Oxford: Oxford University Press, 2005), 3; Leonard Woolf, Sowing: An Autobiography of the Years 1880-1904 (London: Hogarth Press, 1960), 190.

11 John St Loe Strachey, The Adventure of Living: A Subjective Autobiography (London: Hodder and Stoughton, 1922), ch. 3; 'Sutton Court', Country Life, 45 (1910), 22 January 1910; Sir Edward Strachey, Materials to Serve for a History of the Strachey Family, ed. John St Loe Strachey (London: Office of The Spectator, 1899); Charles Richard Sanders, The Strachey Family, 1588-1932: Their Writings and Literary Associations (Durham, NC: Duke University Press, 1953), 28-40; W.C. Lubenow, 'Authority, Honour and the Strachey Family', Historical Research, 76:194 (2003), 511-34. 
of Rothiemurchus. Here, too, there was the whiff of vanished ancestral real estate, and Jane Grant's debt-encumbered forebears had to seek fame and fortune in the Empire, above all, in India. The Stracheys, too, had become primarily an Anglo-Indian family: servants of the East India Company and the Raj, 'continuously from the days of Clive and Hastings' - its colonial officials, army officers, engineers, railway builders, explorers, cartographers, meteorologists, historians and scientific collectors. Among them were Lytton's uncle, Sir John, acting Viceroy and finance minister during the 1870s, and Lieutenant General Sir Richard Strachey, Lytton's father, who, 'in length of service and variety of his claims to distinction', was described as 'the most remarkable of the Stracheys who for four generations ... ha[d] given to India the best portion of their lives'.

In 1872 , shortly after what he intended as a final return from India, the family acquired its first permanent home, Stowey House, a Georgian mansion, on Clapham Common, once the home of James Stephen, a leading member of the sect. Here, in 1880, Lytton was born. His birthplace, though clearly not of his choosing, was ironically emblematic - enough to prompt an absurdly tendentious essay on the decline of Victorian values by Gertrude Himmelfarb: 'From Clapham to Bloomsbury: A genealogy of Morals' ${ }^{12}$ But, in 1884, the family moved to Lancaster Gate - in Bayswater, known for its colonial connections as 'Little India'. And Sir Richard, though greatly admired by Lytton, by now 67, was cut off from his younger children by age, deafness and outside interests: a kindly but remote, olympian figure. ${ }^{13}$

Thus, the household Lytton inhabited for quarter of a century was dominated by his mother, Jane, and his unwed sisters, Dorothy, Pippa, Pernel and Marjorie. Intelligent, cultured, independent women, they did much to nurture Lytton's knowledge and love of literature. But they overindulged the sickly lad. Perhaps that was the trouble: to Lytton, the female, nursing-home atmosphere of Bemax and Dr Gregory's Rhubarb Oil was claustrophobic and inhibiting. But it was also wonderfully stimulating and reassuring. There were many Victorian worlds. And alongside his father's world of technological, scientific and scholarly advancement was the mince, quince and runcible spoon world of Edward Lear: what Leon Edel, in a deft evocation of Lytton's childhood, describes

12 Gertrude Himmelfarb, Marriage and Morals among the Victorians (New York: Knopf, 1986), 23-49.

13 Caine, Bombay to Bloomsbury, 68-9; Holroyd, LSNB, 5-6. 
as 'a verbal world, an eternal nursery' where he danced, dressed up, wrote and acted plays with his sisters, or played 'Blue Fly' to his mother's 'Bumble Bee'. ${ }^{14}$

The Trevelyans too were, by origin, an ancient West Country gentry family. For centuries they had lived at Nettlecombe Court, a honeystoned Elizabethan country house with an estate of 20,000 acres in South Somerset. Here, they perennially served as knights of the Shire - Country Tories, obscure, independent, invariably out of office. Then a series of fortuitous marriages, inheritances that included Wallington and three generations of administrative, political and cultural distinction raised them above the common run of squires. Trevelyan's grandfather, Charles Edward, who inherited Wallington from a cousin, was an energetic, selfmade civil service mandarin, so unbending as to be pilloried by Anthony Trollope in the character of 'Sir Gregory Hardlines'. ${ }^{15}$ An ardent liberal reformer, he helped transform India's trade and education, presided over Irish Famine relief, initiated the rebuilding of Whitehall and authored the famous Northcote-Trevelyan report, British public administration's 'Bill of Rights'. ${ }^{16}$ Life for him was a battlefield, where the forces of altruistic moral progress constantly had to be mobilised against tradition and vested interest. Even more important than his embattled reformist imprint was his marriage to Hannah, beloved sister to Thomas Macaulay, the essayist and historian. Over the years, Macaulay became virtually a member of the family, sharing their house in Calcutta and at Western Lodge on Clapham Common. Living next door to the hallowed 'Battersea Rise' - into the 1850s the shrine of progressive Evangelicalism - the Trevelyan household was closer in spirit to the original 'Saints' than were the later inhabitants of Stowey House. ${ }^{17}$

14 Holroyd, LSNB, 18ff; Leon Edel, Bloomsbury: A House of Lions (London: Hogarth Press, 1979), 35; Lytton Strachey, correspondence with Jane Strachey 1885-1897, with frequent insect greetings, HRHC, Strachey Mss, Box 3, folders 7-8; Box 4, folder 1; Box 5, folders 3-5.

15 G.M. Trevelyan, An Autobiography and Other Essays, 1-5; Laura Trevelyan, A Very British Family: The Trevelyans and their World (London: I.B. Taurus, 2006), 8, 12-15, 24-25; Anthony Trollope, The Three Clerks: A Novel (London: Richard Bentley, 1858).

16 The Northcote-Trevelyan Report of 1854 established the DNA of the modern civil service: recruitment by competitive examination, a graded hierarchy and promotion on merit.

17 John Clive, Macaulay: The Shaping of the Historian (New York: Knopf, 1973), 316-18, 344, 351-3; Humphrey Trevelyan, Public and Private (London: Hamish Hamilton, 1980); Christopher Tolley, Domestic Biography: The Legacy of Evangelicalism in Four Nineteenth-Century Families (Oxford: Clarendon Press, 1997), 196-219, doi.org/10.1093/acprof:oso/9780198206514.001.0001;

L. Trevelyan, A Very British Family, 32-7. 
Yet Charles's son, George Otto, proved an oblique specimen of evangelical descent: 'a hearty Protestant', he inherited his father's reforming zeal and his uncle's bookishness. But he 'did not understand Christianity'. Described as 'a busy pushing man ... for ever writing, speaking, questioning ... ready with remedies for all things', George Otto was a leading Liberal who enjoyed high office in all four Gladstone governments. Yet he never quite decided whether to be a 'stormy' reformer after the manner of his father, or an orthodox Whig like Uncle Tom. He loved the House of Commons, but shied away from the drudgery of political office. Life was too easy; he loved Wallington; he was wealthy and he spread himself thin. A gifted polymath, part politician, part historian, part biographer, a clever versifier, accomplished essayist and classicist, he had, he said, 'a craving for literature, like ... some people for drink'. He had inherited his uncle's narrative skill, to which he added a classical refinement and aristocratic sensibility: qualities evident in all he wrote, from The Competition Wallah, his critical sociology of Anglo-Indian manners after the Mutiny, and Cawnpore, his horror narrative of 1857 , to his fond recreation of the world of eighteenth-century Whig politics in The Early History of Charles James Fox, and his multi-volumed The American Revolution. Best of all was his 900-page Life and Letters of Lord Macaulay, perhaps the finest Victorian biography. ${ }^{18}$

As the setting of George Otto's first writings indicated, in the nineteenth century the Trevelyans also had become an Anglo-Indian family. In three tours of duty spanning the period from 1826 to 1865, Charles Edward served as First Assistant to the Resident in Delhi, private secretary to the Governor-General in Calcutta, Governor of Madras and eventually Finance Minister for the whole Raj. During his last years on the subcontinent from 1862 to 1865, he and Hannah lived next door to Colonel Richard Strachey, then Secretary for Public Works. Charles thought him 'sanguine, ambitious and strongly disposed to partisanship'. ${ }^{19}$ Their politics were very different. As political advisor to the evangelistic Governor-General, Lord William Bentinck, in the 1830s, Trevelyan became a crusader for the replacement of traditional Hindu and Muslim beliefs by Christianity,

18 G.M. Trevelyan, George Otto Trevelyan: A Memoir (London: Longmans, Green, 1932), 20-2; G.O. Trevelyan, The Competition Wallah (London: Macmillan, 1864); G.O. Trevelyan, Cawnpore (London: Macmillan, 1865); G.O. Trevelyan, The Early History of Charles James Fox (London: Longmans, Green, 1881); G.O. Trevelyan, The American Revolution (London: Longmans, Green, 1899); G.O. Trevelyan, Life and Letters of Lord Macaulay (London: Longmans, Green, 1876).

19 Raleigh Trevelyan, The Golden Oriole: A 200-Year History of an English Family in India (London: Secker \& Warburg, 1987), 411-12, 436. 
of indigenous learning by western scholarship and of native vernaculars by English. Cured of superstition and error, 'trained by us to happiness and independence, and endowed with our learning and institutions', Indians, he believed, would learn to govern themselves, and 'we shall exchange profitable subjects for still more profitable allies. ${ }^{20}$

Richard Strachey, by contrast, was typical of the new breed of technocrats who dominated the Raj after the Mutiny. If institutional and educational reform had been the galvanising principle of British rule in the 1830s, modernisation and territorial consolidation were those of the following decades. The system after 1857 was stiffer, more remote: its watchwords control, efficiency, hierarchy and difference rather than reform, progress and assimilation. The downward filtration expectations of the Bentinck era were now seen as a delusion. Far more useful to the imperial project than evangelical teachers, seeking to inculcate 'the diffusive benevolence' of British education, were the builders and modernisers of India's economic infrastructure that would underpin its prosperity under the rule of Viceroys such as the Tory Lord Lytton, after whom Lytton Strachey was named. ${ }^{21}$ So, in the 1870s, as the Trevelyans reaffirmed the Whig vision of Indian self-development and self-government, the Stracheys and their friends restated their belief in enlightened colonial despotism. 'The only hope for India', Sir John Strachey wrote in 1903, was 'the long continuance of the benevolent but strong government of Englishmen': an 'illusion of permanence' accepted by the family till $1914 .^{22}$

20 R. Trevelyan, The Golden Oriole, 139-58, 214-15, 285-7, 326; Charles E. Trevelyan, On the Education of the People of India (London: Longman, 1838); Eric Stokes, The English Utilitarians and India (Oxford: Oxford University Press, 1959).

21 Thomas R. Metcalf, Ideologies of the Raj: The New Cambridge History of India, Vol. 3, Part 4 (Cambridge: Cambridge University Press, 1988), 66-159.

22 C. Trevelyan, House of Commons, Select Committee on East Indian Finances, The Times, 31 July 1873; Letters on The Famine in Bengal, The Times, 27 November 1873; G.O. Trevelyan, The Competition Wallah; James Fitzjames Stephen, Liberty, Equality, Fraternity (dedicated to Sir John Strachey; London: Smith Elder, 1873), xix-xx; Sir John Strachey, India: Its Administration and Progress (3rd ed., with new preface; London: Macmillan, 1903) x-xi; Metcalf, Ideologies of the Raj, 206-11; Ranbir Vohra, The Making of India: A Political History (New York: Armonk, 2014), 87; Francis G. Hutchins, The Illusion of Permanence: The British in India (Princeton: Princeton University Press, 1967), doi.org/10.1515/9781400879649. The family repeatedly stated this belief up to 1914: Lytton Strachey, 'The First Earl of Lytton', IR, 12 (March 1907), 332-8; Strachey, 'The Guides', Spectator, 15 August 1908; Lady Jane Strachey, 'That India Should Not Be Allowed Self-Government', Speech to Lyceum Club, 15 March 1910, quoted in Caine, Bombay to Bloomsbury, 49-50; Joan Pernel to S, 1 March 1914, BL, Add.Ms., 60,726, f. 4. 
The Trevelyan household, like the Stracheys', was a happy one. But it was also masculine and highly politicised. If Lytton was, to some degree, 'made feminine by the femininity of his environment', Trevelyan was made 'manly' by his. Instead of sisters, he had brothers; instead of amateur theatricals, they played Napoleonic war games; they spent hours of outdoor activities on the estate and they walked on a heroic scale. For George especially, mountain walking was a regular tonic and a spiritual experience: 'the best means whereby a man might regain possession of his own soul, by rejoining him in sacred union with nature'. Every Easter from 1899, the 'Trevies' and their friends went on 'The Man Hunt', a five-day game of fellside running, scrambling and sleeping rough in the Lake District, devised by George in an attempt to recreate the excitements of the great chase in Robert Louis Stevenson's Kidnapped. ${ }^{23}$ Yet the brothers - Charles the radical politician, Robert the classicist, and George the historian - were no philistines. Admittedly, they had no small talk. They lectured one another; they were abrupt, plain-speaking, often rude. But they also recited and wrote poetry. George started serious writing at eight with a biographical collage of British leaders in the Napoleonic wars, and at school he composed enormous sub-Tennysonian verse epics on 'Columbus', 'Sir John Franklin', and 'The Prophet' or 'A Song of the People'. ${ }^{24}$

By upbringing and education, as well as lineage, George Trevelyan belonged far more decisively than Lytton Strachey to the political elite. Following his brothers, he was sent to Wixenford, an exclusive preparatory school where the headmaster was a distant cousin of the great Dr Arnold. He went then to Harrow, where his history teacher and housemaster Edward Bowen author of Harrow's school songs - was a close family friend. The school, remodelled after the pattern of Arnold's Rugby, was at the peak of its prestige, having already produced five nineteenth-century prime ministers. But, by the 1880s, Harrow had also become a High Tory preserve, and Trevelyan's politics were radical Liberal. When he was not in the library immersed in Ruskin, Shelley and Tennyson, or in his study, 'keeping the

23 Cannadine, Trevelyan, 144, 146; Mary Moorman, George Macaulay Trevelyan: A Memoir by his Daughter (London: Hamish Hamilton, 1980), 68-70; G.M. Trevelyan, 'Walking', in Clio, A Muse and Other Essays, 1-19, esp. 3-4; R.C. Trevelyan, Windfalls: Notes and Essays (London: Allen \& Unwin, 1944); Alan Hankinson, Geoffrey Winthrop Young: Poet, Mountaineer, Educator (London: Hodder \& Stoughton, 1995), 45-6.

24 Trevelyan's school poetry can be found in Prolusiones ... Scholae Harroviensis (Harrow: Privately Printed, 1892), 51-5; ibid. (1893), 31-44, 54-59; precis of poems in The Harrovian, 18 February, 5 July 1893; Christopher Tyerman, A History of Harrow School, 1324-1991 (Oxford: Oxford University Press, 2000), 355-70, doi.org/10.1093/acprof:oso/9780198227960.001.0001. 
flame of [his] liberalism bright in this dark corner', he was firing off daily screeds to brother Charles, about 'true democracy', 'the gospel of the poor', and 'the progress of the human race', signing his letters 'God Save Ireland', 'God Save the People', or GSI and GSP, for short. But saving Ireland or the People was not Harrow's line, and Trevelyan found himself 'the democratic exception in this high-class establishment'. As a militant agnostic he also refused to take Confirmation - a refusal the headmaster responded to, he said, 'with a religious bigotry worthy of Ignatius Loyola'. ${ }^{25}$

Lytton's schooling, apart from a brief stint at Marie Souvestre's academy, where his French and English literary skills were nurtured, was less select and fortunate. There was Abbotsholme, a spartan, religiose establishment, which advertised itself as 'an advanced Educational Laboratory', devoted to producing the cultural missionaries who would rescue the Empire from degeneracy through 'the natural method' of physical and mental toughening later associated with 'Outward Bound'. After two terms, Lytton's health gave way completely. So he was sent instead to Leamington College, a demi-semi public school that practised the more traditional arts of philistinism, buggery and bullying. Here he learnt to deflect peer hostility by playing clever court jester, a role that soon became second nature. Here, too, he experienced 'that extraordinary sense of melt[ing] into a body literally twice as big as one's own' - boys blessed with the looks, physiques and popularity he so lacked. ${ }^{26}$ The discovery of Plato's Symposium in 1896 came to him 'with a rush of ... surprise [and] relief to know what I feel now, was felt 2000 years ago in glorious Greece'. But living in the shadow of Reading Gaol, he had to fight a sense of uncleanness. By the time he left school, he was an unusual mix: timid, irresolute, insecure, 'naturally biddable', but also self-dramatising, droll, outrageous and secretly rebellious. With his supercilious talk, stick-insect physique, and give-away voice - described as the 'breathless squeak of an asthmatic rabbit' - he was also a provocation: a 'queer' who made even discreet homosexuality dangerous. ${ }^{27}$

25 Moorman, George Macaulay Trevelyan, 21-2; T to G.O. and C. Trevelyan, 23 February, 9 November, [n.d.] November 1892, 5 July 1893, PRL, Trevelyan Mss, GOT 87; T to C.P. Trevelyan, 23 January, 13 February, 19 March, 'Easter', 'April-May', 13, 14, 17, 21 May, 1, 18, 25, 29 June, 5 , 19 July 1893 (all from Harrow), PRL, Trevelyan Mss, CPT, Ex 194; Trevelyan, An Autobiography and Other Essays, 3, 9, 15.

26 Holroyd, LSNB, 28-32; Caine, Bombay to Bloomsbury, 113-15.

27 S, Diary, 13 November 1996, in Holroyd, Lytton Strachey by Himself, 86; Julie Anne Taddeo, Lytton Strachey and the Search for Modern Sexual Identity: The Last Eminent Victorian (New York: Harrington Park Press, 2002), 22-3; Holroyd, LSNB, 42-3; W.G. Robertson, Time Was: The Reminiscences of W. Graham Robertson (London: Hamish Hamilton, 1931), 16-17. 
Trevelyan was a 'serious gowk': irreligious, but terribly earnest. And he recognised it: 'I am forced to confess,' he wrote his brother, 'we inherit the moral stamina produced in Grandpa by religion and apply it straight to our infidel sense of duty.' Shortly before going up to Cambridge, he told Charles of his tasks in 'the battle for life'. His ideal was 'the wedding of the modern democratic spirit, the spirit of duty in its highest form, to modern literature'. But, he wrote, 'literary people are not most of them, democratic', and 'Cambridge people are intellectual but not serious'. So, 'unless I keep my fire ever kindled within me, I shall soon forget my "motif" and become a mere "littérateur"'!28 In addition to the hard work that earned him a First, a Prize essay and a Trinity fellowship at the age of 21 , he was active in many progressive causes - Irish Home Rule, opposition to British policies in Egypt, India and, above all, 'the Devil's kitchen in South Africa'. He wrote passionately on the 'Condition of England' problem, and devoted much of his spare time to adult education, organising Trinity summer schools and teaching at the Working Men's College in London. ${ }^{29}$

Strachey arrived in Cambridge seven years later, in 1899. University for him was not 'a battle for life', still less a test of political engagement or good works. Rather it was a liberation, a place of unrestrained talk and enduring friendships - with the male core of 'Old Bloomsbury' - or, as Leon Edel puts it, 'a romp, a lark, a phallic universe' ${ }^{30}$ Early in his first year, he was 'taken up' by Trevelyan. As a junior fellow, Trevy was responsible for sponsoring Lytton's election to a College Scholarship, to the elite Sunday Essay Club and, above all, to the Cambridge Apostles. He was greatly impressed with Lytton's poetic and literary abilities, and he looked to him as a potential ally in the defence of the literary and humane traditions of English historical writing. "He will write history well some day, and I am leading him out of cynicism into the dry land of Carlylean defiance and pity,' Trevelyan told his mother, 'he is worth leading and I am getting very fond of him.' He is most friendly and kind,' Strachey told his mother, 'and very much like I imagined his father to be.' But there was an undertow of passive aggression in his response: 'He is very eager', he wrote, but 'too

28 T to C.P. Trevelyan, 19 July, 4 August 1893, PRL, Trevelyan Mss, CPT, Ex 194; Moorman, George Macaulay Trevelyan, 35-6; L. Trevelyan, A Very British Family, 117.

29 T to G.O. Trevelyan, 12 May, 17, 20 October, 12 December 1900, PRL, Trevelyan Mss, GOT 91; G.M. Trevelyan, 'Past and Future', in C.F.G. Masterman, ed., The Heart of Empire (London: Unwin, 1901), 398-415; G.M. Trevelyan, 'The White Peril', The Nineteenth Century, 50 (1901), 1043-55.

30 Edel, Bloomsbury, 39, 44; Lytton Strachey, 'A Sermon Preached before the Midnight Society', 5 May 1900; Strachey, 'Conversation and Conversations', 3 November 1901, BL, Add.Ms., 81,813, folder 1,8 . 
earnest, patristic and virulent' and 'somewhat piteous' ${ }^{31}$ Lytton found the 'overwhelming enthusiasm' and heavy-handed mentoring 'alarming', and he started poking fun, as in the parable of 'Cleanthes the Stoic':

'For the last six months,' said Cleanthes, 'I have been very busy. I have written four more chapters of my history of Cos ... I have given several lectures ... attended countless ... committees, boards and syndicates ... walked from Athens to Corinth ... twenty five times ... taken a great deal of exercise, and done a great deal of work, a great deal of talking and a great deal of good.' 32

The tension reflected not only temperamental dissonance, but also generational change. Generational rupture was to become one of the leitmotifs of Strachey's thought. His father, born within months of the battle of Waterloo, was too old. So were the 'bilious' uncles he recalled at Lancaster Gate. Admittedly, his mother was younger, and Lytton was strongly tied to her aesthetically and emotionally; however, she was 'a consenting and approving Victorian', was 'not up to date in morals', and 'ha(d) never heard of buggery - at any rate in her own family'. There was much he could not tell her: 'Oh, how dreadful to be a mother', he said to Maynard Keynes, 'how terrible to love so much and know so little. ${ }^{33}$ According to Russell's somewhat jaundiced verdict:

J.M. Keynes and Lytton Strachey both belonged to the Cambridge generation about ten years junior to my own. We were still Victorian; they were Edwardian. We believed in ordered progress by means of politics and open discussion ... The generation of Keynes and Strachey ... aimed rather at a life of retirement among fine shades and nice feelings, and conceived of the good as consisting in the passionate mutual admirations of a clique of the elite. ${ }^{34}$

31 T to S, 2 March 1900, 22 March 1902, BL, Add.Ms, 60,732, ff. 180-5; T to Caroline Trevelyan, 1 December 1900, PRL, Trevelyan Mss, GOT 94; S to Joan Pernel Strachey, 10 March, 3 May 1900, BL, Add.Ms., 60,724, ff. 86-92; S to Jane Strachey, 11 March, 29 April 1900, 24 March 1902, HRHC, Strachey Mss, Box 4, folder 2; Holroyd, LSNB, 61-2; Cannadine, Trevelyan, 41-2.

32 Strachey, 'Aphorisms', BL, Add.Ms., 81,916, no. 40; partly printed in Gabriel Merle, Lytton Strachey (1880-1932): Biographie et critique d'un critique et biographe (Paris: Honoré Champion, 1980), 911.

33 Vanessa Bell to Virginia Woolf, 18 January 1918, New York Public Library, Berg Collection, Virginia Woolf Papers, Incoming Correspondence; Quentin Bell, Virginia Woolf, A Biography (2 vols; London: Hogarth Press, 1972), vol. 2, 60; Virginia Woolf to Vanessa Bell, 17 January 1918, in Nigel Nicolson and Joanne Trautmann, eds, Letters of Virginia Woolf, Volume II (London: Hogarth Press, 1976), 212-13; S to John Maynard Keynes, 27 February 1906, King's College, Cambridge, (KC), Keynes Mss, PP/45/316/2, f. 130.

34 Bertrand Russell, 'Portraits from Memory', The Listener, 17 July 1952, 97, reprinted in Russell, Portraits from Memory and Other Essays (London: Allen \& Unwin, 1956), 73-5. 
In Trevelyan, this sense of generational rupture was wholly absent. Independent he might be; rebel he was not. George Otto, born in 1838, active in politics and history writing until the First World War, was his natural confidante on matters literary, historical and political, as was Lady Caroline, born in 1849 and into the 1920s an advanced reformer, on his social, educational and personal concerns. And if his parents' interests reached into the twentieth century, his own reached back to the nineteenth, through his father to Macaulay and Holland House, and through his mother to the Manchester mercantile dynasties and the world of the First Reform Bill. So completely did he project the values of his elders that by the time he reached his 30s, he was seen by his Cambridge juniors as an 'old dear' - an anachronism. ${ }^{35}$

By 1900, the Trevelyans had become very wealthy. Frugal habits, astute marriages, culminating in George Otto's to Caroline Philips, the inheritor of a cotton fortune, and a large copyright income from Macaulay's and George Otto's books saw to it that the brothers enjoyed large private incomes. But George was too angular a character, too complicit with the demise of privilege, too much a son of Clapham simply to enjoy his position. Somehow he had to earn it. So, he spoke of the need for selfdiscipline and drove himself all his life. ${ }^{36}$ The Stracheys were relatively poor, and Lytton was painfully aware that his family had come down in the world. Long before Virginia Woolf patented the phrase, he wrote of his longing for 'a room of one's own', and he envied the 'uncontending ease' of the Trevelyans. But he had none of their guilts either. Cosseted from infancy, he believed he had a right to the good things of life. It could never be said of him as of Trevelyan, 'his was a character inadequately warmed by self-indulgence'. Like the Carpenter, he wanted another slice. ${ }^{37}$

It was in the Apostles that the differences between Trevelyan's late Victorian angst and Strachey's Edwardian levity came to a head. Discussions at the turn of the century, under the influence of G.E. Moore - the great Cambridge guru of the era - focused on the distinction between

35 S to Leonard Woolf, 23 March 1903, 1 June 1905 (on Russell as 'a medieval figure'), 6 February 1907 (Rupert Brooke on Trevy as 'an old dear'), HRHC, Strachey Mss, Box 4, folder 5.

36 Cannadine, Trevelyan, 47; John Burrow, review of George Macaulay Trevelyan by Mary Moorman, The Times, 1 July 1980; John Vincent, 'G.M. Trevelyan's Two Terrible Things', LRB, 2:12, 19 June 1980. 37 S to Duncan Grant, 23 August 1909, BL, Add.Ms., 57,932; 'Walruses and Carpenters', Spectator, 9 December 1911. This article was signed 'Z', as were a number of Strachey's other contributions to the Spectator between 1908 and 1912. In this article, S refers to Trevelyan and Dickinson as 'Walruses' and to himself and some of his fellow Apostles as 'Carpenters'. 
'reality' and 'phenomena', and on the nature of 'the good'. Was 'reality' a timeless area of truth and contemplation or was it the material world? And was being good or doing good more important: was the active or the contemplative life the ideal? Trevelyan was fully convinced that 'the only way of getting at reality, was by the phenomenal expression of it'. As he put it to his mother, 'If life consisted of right thinking, it might be successfully lived; but, it consists also of right doing and right creating, a very different matter'. There was no point in feeling or even being good if one did not improve the world. 'Action', he told the Apostles, was 'the main thing in life': it was only by action, that one could make oneself a human agent capable of ethical thinking at all. Doing good also meant fighting evil: 'Liberalism,' he told Moore was 'the forcible social realization of the principle of Hatred of Evil, which I take ... to be an essential part of love of good. 38

For Moore and Strachey, however, the ultimate realities were 'good states of mind'. These were intrinsic and were not associated with 'instrumental actions'. They consisted of timeless, passionate states of contemplation and communion. The appropriate subjects of contemplation and communion were a beloved person, beauty and truth, and the prime objects in life were love, the enjoyment of aesthetic experiences and the pursuit of knowledge' - to the exclusion of all else. Strachey deplored the belief that 'you are definitely improved if you do social work and go into Parliament or an engagement at the Working Men's College', and that 'the dynamic life is the proper one to lead'. This view was, for him, 'detestable. I want to throttle it', he said, 'put it out of the way. The phenomenal world oppresses me like an undigested nightmare'. ${ }^{39}$ According to Russell, there was 'a long drawn out battle' between Trevelyan and Strachey for the soul of the Apostles, 'in which Lytton was on the whole victorious'.

38 T to Caroline Trevelyan, April-May 1896, PRL, Trevelyan Mss, GOT 89, ff. 84-5; T to G.E. Moore, July-September 1895, esp. 26 July 1896 (a 20-page letter); Moore Papers, Cambridge University Library (CUL), Additional Mss, 8330, 8T/12/4-8; Cambridge Apostles' Papers, Minute Books, 1893-1898, KC: KCAS/39/1/12: 6 June 1896, 13 February, 1 May 1897, and esp. 21 May 1898 in response to Moore's paper entitled, 'Shall we think without acting, or act without thinking?'. 39 John Maynard Keynes, 'My Early Beliefs', a paper read to the Bloomsbury Memoir Club in 1938, is the classic formulation. See S.P. Rosenbaum, The Bloomsbury Group: A Collection of Memoirs, Commentary and Criticism (revised ed.; Toronto: University of Toronto Press, 1995), 82-95; S to G.E. Moore, 11 October 1903, CUL, Moore Papers, Additional Mss, 8330, 8T/44/1; Leonard Woolf, 'George or George or Both' Paper to the Cambridge Apostles, 9 May 1903, summarises the conflict between George Trevelyan and George (or, as he preferred, G.E.) Moore: Leonard Woolf Archive, Part 2, O/2 University of Sussex Special Collections; Strachey, 'Shall We Go the Whole Hog?', Paper to the Cambridge Apostles, 25 February 1905, BL, Add.Ms., 81,890, in Avery, The Works of Lytton Strachey: Early Papers, 99-103. 
Russell thought it was all about sex - and homosexual relations, hitherto dormant, became rampant in the society under the influence of Strachey and Keynes - but it ranged more widely: it was also about art and politics, good states of mind and good deeds, the active and the passive life..$^{40}$

At this stage in his career, Trevelyan, according to Leonard Woolf, was 'a fiercely political young man'. In 1903, in protest at Bury's inaugural on 'the science of history', he left the introverted world of academe to devote himself to public writing and good works, and in 1904, he married Janet, daughter of Mary Ward, the celebrated novelist, philanthropist and grandchild of Dr Arnold. ${ }^{41}$ Living on the edge of Pimlico, they were both prominent in a range of progressive causes - children's play centres, conservation, land reform, open diplomacy. And George was a member of various organisations formed in support of national independence and reform movements in Europe and the Middle East. In 1903, he had established and funded a new progressive journal, The Independent Review, a twentieth-century 'Edinburgh' review of 'advanced views on politics and ideas ... above party', and he recruited congenial Apostles including Russell, Dickinson, Roger Fry and Strachey to write for it. Infused with the ethic of service to the people, and by the philosophe ideal of stamping out ignorance and prejudice through education - inspired, he said, by 'the career and example' of Voltaire to put his 'wealth' and 'talent' to more than 'the selfish ... egotism which we know as "academic" - he also lectured many times a week at adult educational institutions: the Working Men's and Morley Colleges, Toynbee Hall, and Mary Ward's charitable foundation, the Passmore Edwards Settlement in Bloomsbury. ${ }^{42}$

But it was primarily as a historian and biographer that he meant to galvanise 'the modern democratic spirit'. His books were all designed as public statements, books that would 'make a difference', Liberal 'tracts for

40 Russell, Autobiography, I, 74; Cannadine, Trevelyan, 42; Richard Deacon, The Cambridge Apostles: A History of Cambridge University's Elite Intellectual Secret Society (London: R. Royce, 1985), 55-68 overstates the case.

41 G.M. Trevelyan, 'The Latest View of History', IR, 1 (1903), 395-414. On the marriage with Janet Ward, see 56 letters between T and Janet Ward in 1903 and 1904; also Janet Ward to Mary Ward, 9 February, 3 April 1904, PRL, Trevelyan Mss, MM 2/2/1; T's letters to his parents, 1903-4, PRL, Trevelyan Mss, GOT 96. Strachey's take on the wedding is found in S to Leonard Woolf, 20 March 1904, in Paul Levy, ed., The Letters of Lytton Strachey (London: Penguin 2005), 23-4.

42 'A Plea for a Programme', IR, 1 (1903), 1-27; T to S, October 1903, BL, Add.Ms., 70,732, f. 187; Moorman, George Macaulay Trevelyan, 51; John Sutherland, Mrs. Humphry Ward: Eminent Victorian, Pre-eminent Edwardian (Oxford: Clarendon Press, 1990); Janet Penrose Trevelyan, The Life of Mrs. Humphry Ward (London: Constable, 1923). 
the times'. He honestly believed that the lives of the heroes he laid before the public - freedom fighters such as Garibaldi or reformers such as John Bright, teaching by example - could transform brutalised artisans into good citizens and culturally fulfilled human beings. 'Service to mankind,' he wrote, 'though it may be the same thing as service of truth, must be put first, in so far as the two are separate. I do not mean I should falsify history to serve any end, but that I must act as an interpreter of history, in the truest sense, to all those who ... read books.' But to reach the reading public, history must be accessible. Hence, Trevelyan's opposition to the new 'scientific' orthodoxy promoted by Bury - to the methods of painstaking research and dry 'objectivity', which so easily turned into 'unenlightened pedantry'. ${ }^{43}$

He had inherited Macaulay's view of history as a branch of literature and an essential part of the national culture, and he was a great believer in the symbiosis of literary history and progressive politics. But he surpassed his great-uncle in his enthusiasms and sensibilities. Unlike Macaulay, he genuinely warmed to the freedom fighters and radicals of the past. Much of his enthusiasm came from Carlyle. The greatest of Victorian prophets, the Sage of Chelsea was at the height of his repute in Trevelyan's early years. And Trevy was a fervent disciple. Like Carlyle, he believed that history was 'the essence of innumerable biographies', that its function was to 'breed enthusiasm' and that its method was imaginative, empathetic, rhetorical and exemplary. History, he said, was 'a perpetual evangel': it was 'man's ... attainment that [was] the great lesson of the past and the great theme of history'. Here too, one can sense the presence of Lord Acton, the presiding genius of the Cambridge History, who first set him on the path of historical writing. For Acton insisted on the importance of individuality, morality and free choice: 'soul cannot be mixed with soul', he declared, 'each individual stands apart'. ${ }^{44}$

43 Moorman, George Macaulay Trevelyan, 51-2; T to G.O. Trevelyan, 1 August 1895, [undated] 1896, PRL, Trevelyan Mss, GOT 88, ff. 11-13, 89, ff. 30ff; Vincent, 'G.M. Trevelyan's Two Terrible Things'.

44 Victor Feske, From Belloc to Churchill: Private Scholars, Public Culture and the Crisis of English Liberalism (Chapel Hill: University of North Carolina Press, 1996), 4-5, 141-2, 150; Cannadine, Trevelyan, 26-31; Trevelyan's passion for Carlyle can best be followed in his correspondence with his parents and brothers between 1895 and 1901: see PRL, Trevelyan Mss, GOT 88-94; CPT, Ex 195-7; Raina, George Macaulay Trevelyan, 21, 82; G.M. Trevelyan, 'Carlyle as an Historian', The Nineteenth Century, 48 (September 1899), 493-503; Trevelyan, 'Carlyle, Cromwell and Professor Firth', IR, 4 (1904-5), 302-8; Trevelyan, England in the Age of Wycliffe (London: Longmans, Green, 1899), 3-5; Trevelyan, 'Lord Acton's Liberalism', IR, 2 (1904), 651-6. 
The familiar nodal points of the Whig story naturally formed the substance of Trevy's early writing. But his treatment of these episodes broadened and radicalised ancestral themes in a way that reflected the social, economic and international preoccupations of his age. His histories focused on the heroic action of individuals - Wycliffe, Hampden, Bright, Grey, above all Garibaldi, whose career he celebrated in three vivid volumes from 1906 to 1911 - to bring about religious and political freedom, democracy, reform and national liberation against the odds. As such, they illustrated a fundamentally optimistic storyline: a progressive morality tale wrought by heroes against injustice. ${ }^{45}$ But just as important to him as 'Clio the evangel' was 'Clio the muse'. Trevelyan was a poet manqué: to study the past was to experience 'the poetry of Time'. History for him was the repository of 'rest and beauty so alien to the spirit of our age', 'an ever-present antidote' to its 'social ills' and 'visions of ugliness'. So his progressivism was undercut by nostalgia. In recapturing the landscapes of the past - and his sense of place was far more acute than his understanding of persons - Trevelyan, the celebrant of unspoilt nature, critic of industrialisation, would-be rescuer of ordinary lives from the urban 'abyss', also mourned the collapse of traditional communities and the passage of time itself. ${ }^{46}$

Biographers are in the character business, and Trevy's heroes were impossibly noble. He was baffled by psychological complexity, divided loyalties, mixed motives, worldliness, cynicism. Sexual relations disturbed him. Private life lay outside his brief. His idealisation of, and self-identification with, Garibaldi was especially strong. But it was also, in Richard Holmes's telling epithet, 'pre-biographic': a form of self-projection never counterbalanced by the process of distancing or disillusion. By rewalking all Garibaldi's marches across Italy - reliving and internalising the story - Trevelyan acquired a second, adventitiously heroic, identity. By fusing his persona as a frustrated political activist with his protagonist's, and his protagonist's agency with Italy's, he joined the personal with the national. Conversely, Garibaldi's enemies were villains out of grand guignol, building futile barriers against the flow of history. Trevelyan's biographies were very successful, but in the long run their

45 G.M. Trevelyan, Wycliffe; Trevelyan, England under the Stuarts (London: Methuen, 1904); Trevelyan, The Life of John Bright (London: Constable, 1913); Trevelyan, Lord Grey of the Reform Bill (London: Longmans, Green, 1920; partly written before 1914). For Garibaldi, see below, fn. 47.

46 G.M. Trevelyan, 'The Latest View of History', 412-14; Trevelyan, Clio, A Muse and Other Essays, 140-76; Trevelyan, 'The Present Position of History', Inaugural Lecture, Cambridge 1927, 15-16, also published in Clio, A Muse and Other Essays (2nd ed.; London: Longmans, 1930), 177-96; Cannadine, Trevelyan, ch. 4; Trevelyan, 'The White Peril', 1043-55. 
success was intellectually disabling. He went on telling familiar reverential stories into the 1920s - adding further slabs to the public tombstones Strachey ridiculed in Eminent Victorians. ${ }^{47}$

Strachey was one of those whom Trevy had lined up to write against the new scientific orthodoxy in The Independent Review. But Strachey's view of the journal was ambivalent - he called it 'The Phenomenal Review' - and his response to Bury was never published. For his essay on 'The Historian of the Future' found both Bury and Trevelyan guilty of confusing identity and purpose, the nature of history with the good it was supposed to do. Unfortunately, he continued - drawing on Moore's distinction between intrinsic and instrumental value - people were never satisfied with things of value, but had to question their uses or the ends they served. Literature, music and art, however, were simply good in themselves; it was otiose to show they produced good results. So, too, history: it was not a vocational discipline like law or medicine, nor was it a moral parade ground or a social service industry. Its role was to amuse and delight. Its value was purely aesthetic. 'The past is irrevocable,' Strachey wrote, 'its good and evil are fixed and done with; and we can look at it dispassionately as if it were a work of art. ${ }^{3} 8$

Yet Lytton's first formal attempt at writing history was far from dispassionate. Rather, it was a piece of family piety. Both Lytton's uncle and family friend Fitzjames Stephen had written in defence of Hastings's policies in India and against his detractors. So Lytton's fellowship essay on 'Warren Hastings, Cheyt Sing and the Begums of Oude' was a chip off the family block. Written at a time when enlightened colonial despotism was being celebrated as never before, it was engaged and partisan. ${ }^{49}$

47 G.M. Trevelyan, Garibaldi's Defence of the Roman Republic (London: Longmans, Green, 1907), 2-4, 7, 23-4; Trevelyan, Garibaldi and the Thousand (London: Longmans, Green, 1909), 3, 7-9; Trevelyan, Garibaldi and the Making of Italy (London: Longmans, Green, 1911), 289-91, 296; Lucy Riall, Garibaldi: The Invention of a Hero (New Haven, CT: Yale University Press, 2007), 13-14; Richard Holmes, Footsteps, Adventures of a Romantic Biographer (London: Penguin, 1985), 66-8; Alastair MacLachlan, 'Becoming National: G.M. Trevelyan, The Dilemmas of a Liberal (Inter) nationalist', in 'Nationalism and Biography: European Perspectives', Jonathan Hearn and Christian Wicke, eds, Humanities Research, XIX:1 (2013), 28.

48 S to Leonard Woolf, 28 August 1903, HRHC, Strachey Mss, Box 4, folder 5; Lytton Strachey, 'The Historian of the Future', BL, Add.Ms., 81,893, no. 2; Avery, Lytton Strachey: Early Papers, 51-64; $S$ to J.T. ('Frank') Sheppard, 17 March 1906, KC, Sheppard Papers, JTS 2/194.

49 Sir James Fitzjames Stephen, The Story of Nuncomar and the Impeachment of Sir Elijah Impey (2 vols; London: Macmillan, 1885); Sir John Strachey, Hastings and the Rohilla War (Oxford: Clarendon Press, 1892). Strachey acknowledged the advice of his uncle in the writing of his thesis. For the imperial moment' in biography, see Sir William Hunter's Rulers of India series (28 vols; Oxford: Clarendon Press, 1889-1902), including L.J. Trotter, Warren Hastings (1890); John Knox Laughton's English Men 
Hastings had fallen foul of the prevailing parliamentary and commercial mode of governance advocated by Burke and the Whig managers at the time of his impeachment in 1786, and subsequently endorsed by James Mill and Macaulay in their utilitarian evaluations of Hastings's rule. ${ }^{50}$ Picking through the controversies of Hastings's eight-year trial required painstaking research and close forensic analysis, but superseding Macaulay required more than scientific weighing of evidence. To Lytton:

In general, books are read solely for the pleasure they give; and ... Macaulay will triumph, until there arises a greater master of the art of writing, who will ... invest the facts of Indian history with the glamour of literature, and make truth more attractive than fiction.

So his account transformed his hero from the autocrat of orthodox Whig accounts into benevolent imperial icon, and substituted a morality tale on malignant political partisanship for one on Oriental despotism. Like Macaulay and Trevelyan, he could not bear history to be dull; like them he was inclined to substitute ornate description, rhetoric and melodrama for cool analysis. Torn between documentary fact-finding and dramatic storytelling, between history as science and history as art, his essay was characterised by a confusion of styles and targets - a narrative puffed out by heated refutations of Burke or Mill, and critical evaluation of evidence subverted by elaborate literary tableaux. The examiners were unimpressed, and twice he was denied a fellowship. ${ }^{51}$

of Action series (16 vols; London: Macmillan, 1889-1905), including Sir Alfred Lyall, Warren Hastings (1891); and the Builders of Greater Britain series (12 vols; London: Chapman \& Hall, 1890-1904), including G.B. Malleson, Life of Warren Hastings: First Governor-General of India (1894).

50 For the Strachey and Stephen families' hostility to 'the great criminals' (Lytton's term) Burke, Mill and Macaulay, see K.J.M. Smith, James Fitzjames Stephen: Portrait of a Victorian Rationalist (Cambridge: Cambridge University Press, 1988), ch. 6, doi.org/10.1017/CBO9780511558597; Lytton Strachey, 'The Political Wisdom of Burke', Spectator, 31 October 1908; Strachey, Letter (in reply to Professor J.B. Bury), 7, 14 November 1908 (both signed Z); Sophia Weizman, Warren Hastings and Philip Francis (Manchester: Manchester University Press, 1929); F.G. Whelan, Edmund Burke and India: Political Morality and Empire (Pittsburgh: Pittsburgh University Press, 1996); Edward Strachey, 'James Mill', Spectator, 15 April, 1 July 1882.

51 Lytton Strachey, 'Warren Hastings, Cheyt Sing and the Begums of Oude' (1905, 1906), unpublished, two versions in Firestone Memorial Library, Princeton University, Robert Taylor Collection, Mss, 121, 122; 'Introduction' of the later version in Michael Holroyd and Paul Levy, eds, The Shorter Strachey (Oxford: Oxford University Press, 1980), 225-32 at 225; earlier version in BL, Add.Ms., 81,890 (Greaves Essay Prize, September 1901); later version, Spectator, 12 March 1910; S.P. Rosenbaum, 'Lytton Strachey and the Prose of Empire', in Susan Dick, Declan Kiberd, Dougald McMillan and Joseph Ronsley, eds, Omnium Gatherum: Essays for Richard Ellmann (Montreal: McGill-Queen's University Press, 1989), 122-33; Bruce B. Redford, 'The Shaping of the Biographer: Lytton Strachey's Warren Hastings, Cheyt Sing and the Begums of Oude', Princeton University Library Chronicle, 43 (1981), 38-52. 
Cast back into 'a limbo of unintimacy' at Lancaster Gate, Lytton had to earn a living with periodic short essays and book reviews. At Cambridge, in his scatalogical verses, smutty dialogues, short stories and especially his papers to the Apostles - on bodily functions and propriety, art and indecency, aesthetics and morality, progress and savagery, self-control and self-expression, marriage and the death of love - he had learnt that the best way to startle, amuse and delight his peers was to deploy humour, irony, mockery, a sense of paradox and of disproportion; qualities he was to perfect in Eminent Victorians. ${ }^{52}$ And from 1904 on, in essays and book reviews - 10 for Trevelyan's journal - he began to apply his iconoclasm to historical and literary subjects, and to complement his subversive stance with a style that Barry Spurr has aptly termed 'camp mandarin'. ${ }^{53}$ Over the next decade, he cultivated a cosmopolitan, Francophone persona, and he fine-tuned his exotically 'queer' sensibility in recoil from what he depicted as Victorianism.

'To someone born in 1880,' he wrote, 'the Victorian age has the odd attractiveness of something at once very near and very far off; like ... those queer fishes one sees behind glass at an aquarium.' Simultaneously modern and ancient, an age of science and faith, it was somehow 'unaesthetic to its marrow bones'. The Victorian age, he wrote, 'great in so many directions' - he was thinking of its scientists and empire builders - 'was not great in criticism, in humour, in the realistic apprehension of life'. The Victorians were ineradicably 'phenomenal'. From this deficiency flowed multiple defects: the crushing conventionality, the Puritan morality, the work ethic, the infinite deferment of pleasure, the intellectual dishonesty, the lack of self-awareness, intuition or psychological insight, the 'ineradicable instinct for action and utility' that destroyed all sense of art. Victorianism, he suggested, was shaped by a tug of war between Puritanism and Romanticism, propriety and conviction, excessive moralism and rampant

52 Apostles' Essays 1902-1912, Dialogues, Short Stories, all in Avery, Lytton Strachey: Early Papers, 1-199; Cambridge Apostles' Papers, Minute Books 1902-9, 1909-1914: 10 May, 25 October 1902; 31 January, 14 March, 16 May, 14 November 1903; 20 February, 21 May, 19 November 1904; 25 February, 27 May, 2 December 1905; 27 October 1906; 27 May 1907; 24 October 1908; 28 May 1910; 20 May 1911; 27 January, 11 May 1912, KC: KCAS/39/1/14-15.

53 Barry Spurr, 'Camp Mandarin: The Prose Style of Lytton Strachey', English Literature in Transition 1880-1920, 33:1 (1990), 31-45; G.L. Strachey, Landmarks in French Literature (London: Williams and Norgate, 1912). 
materialism, self-denial and self-expression, which, like the meeting of two weather systems, generated what he called an 'atrocious fog ... of sentiment'. ${ }^{54}$

These were the characteristics he explored in a number of different guises in some of the writers Trevelyan particularly admired: Scott, Carlyle, Tennyson, Sidgwick, Morley, Maitland. ${ }^{55}$ But Strachey singled out three for particular disparagement. One was George Meredith. In 1906, Trevelyan had written a study of The Poetry and Philosophy of Meredith. Strachey's response was scathing, for typically, instead of focusing on the poetry, Trevy filled his book with its 'social messages' and 'moral teaching', crushing 'all sense of art between the millstones of [his] earnest moral endeavour and deep political conviction'. Six years later, when he contributed to the Memorial Edition of Meredith's works, Strachey's criticism extended from the expositor to the subject: the Victorians, he remarked to Virginia Woolf, 'seem to me a set of mouthing, bungling hypocrites'. Another target was Macaulay, with whom he warred all his life: a Puritan turned Philistine, who invariably confused culture with better street lighting and morality with middle-class respectability. ${ }^{56}$ But the most scathing of his essays was reserved for Trevelyan's other great-uncle, Matthew Arnold, the high priest of Victorian cultural criticism who had popularised the idea of great literature as a form of moral uplift. Entitled 'A Victorian Critic', and opening with the suggestion that 'an Old Victorian Club' should be started in 'some quiet corner of Pimlico', the essay asked sarcastically, 'how could anyone ... take literature seriously', when there was life to be

54 Holroyd, LSNB, 139-40; S to Leonard Woolf, 9 September 1904, in Levy, The Letters of Lytton Strachey, 32-3; Lytton Strachey, 'A Statesman: Lord Morley', War and Peace, 5 (February 1918), in Strachey, Biographical Essays (BE) (London: Chatto \& Windus, 1948), 281-4; Strachey, 'A Victorian Critic', NS, 1 August 1914, in Strachey, Literary Essays (LE) (London: Chatto \& Windus, 1948), 209-13. 55 Lytton Strachey, 'Not by Lockhart', The Speaker, 15 October 1906; Strachey, 'Some New Carlyle Letters', Spectator, 10 April 1909; Strachey, 'Catullus and Lord Tennyson', in Avery, Lytton Strachey: Early Papers, 159-64; for Sidgwick, see Holroyd, LSNB, 139-40; S to John Maynard Keynes, 11 March 1906, and Keynes to S, 8 March 1906, KC, Keynes Mss, PP/45/316/2, ff. 152-3, 158-9; S to G.E. Moore, 28 March 1906, CUL, Moore Mss, T8/44/7; for Maitland, see Apostles' Paper, 20 May 1911, in Paul Levy, ed., The Really Interesting Question and Other Papers (London: Weidenfeld \& Nicolson, 1974), 121-6.

56 S to Leonard Woolf, 2 December 1905, HRHC, Strachey Mss, Box 4, folder 5; G.M. Trevelyan, The Poetry and Philosophy of George Meredith (London: Constable, 1906); Clive Bell, Review, in Cambridge Review, April 1906; S to Clive Bell, 17 March 1906, BL, Add.Ms. 71,104, ff. 13-14; S to Woolf, 8 November 1912, in Leonard Woolf and Lytton Strachey, eds, Virginia Woolf and Lytton Strachey: Letters (London: Hogarth Press, 1956), 42-3; Strachey, 'Macaulay's Marginalia', Spectator, 16 November 1908; S to G.L. Dickinson (on 'the damned weed of Macaulayism'), 26 May 1918, KC, Dickinson Papers, GLD/5/23; Strachey, 'Congreve, Collier and Macaulay', Nation \& Athenaeum (Nation), (34), 13 October 1923, 'Macaulay', Nation, (42), 21 January 1928, both in LE, 53-7, 195-201. 
lived, action to be taken, duty to be done? Hence 'that ingenious godsend, the theory of the Criticism of Life', which enabled one to write poetry and be 'an inspector of schools', admire Shakespeare and Samuel Smiles, serve the Muses and Mammon. ${ }^{57}$

'A Victorian Critic' was published on 1 August 1914, and the differences between Strachey and Trevelyan were sealed by the outbreak of the First World War. Six months earlier, the two of them had discussed Bury's A History of Freedom of Thought, which described the growth of religious toleration in early modern Europe. Bury explained how 'religious warfare and persecution had been abolished by the quiet thinking of rationalists and sceptics' who showed that intolerance simply did not work. Trevelyan was convinced that the same transformation could take place in military thought, and he declared himself a convert to Norman Angell's 'practical' pacifism, which argued that war was counterproductive, unsustainable and hence impossible. Strachey's response to the congratulatory story of 'Toleration Victorious, all coleur de rose' was quite different. Was it really possible, he asked, that 'such [a] deeply rooted instinct as the love of persecution ... should have disappeared?' Intolerance had merely 'shifted its concern' from metaphysics and science to life and literature; instead of burning heretics and imprisoning astronomers, the authorities now persecuted writers and suppressed indecency: if not Galileo, then Oscar Wilde. ${ }^{58}$

In August 1914, after a brief opposition to British intervention in the name of practical pacifism and international rationality, Trevelyan became an ardent liberal warrior. Granted his commitment to public duty and progressive causes, his activism and his need to improve the world, he was programmed to subscribe to most wartime 'myths'. He was soon convinced that this was a war of duty and national honour, of little peoples against ancient dynastic empires, of self-determination, liberty and democracy against militarism and autocracy. It was, for him, a war that would complete the progressive nineteenth-century story and eventually through the foundation of a new international order lead to the ending of war itself. Too blind for active service, he spent his war in

57 Lytton Strachey, 'A Victorian Critic', LE, 209-14.

58 T to S, 16 December 1913, BL, Add.Ms., 60,732, ff. 193-4 (arranging a meeting at Strachey's country retreat); J.B. Bury, A History of Freedom of Thought (London: Home University Library, 1913); G.M. Trevelyan, 'Norman Angell's New Book', War \& Peace, 2 (March 1914), 164-5; [Strachey], 'Avons-nous changé tout cela', NS, 22 November 1913, 204-6; Strachey, 'Bonga-Bonga in Whitehall', NS, 17 January 1914, 459-60. 
non-stop public service: diplomatic and military missions to Serbia and Romania; propaganda activities in Rome and the United States; and for three years Commandant of the British Red Cross Unit on the Italian Front. He also wrote morale-boosting articles on behalf of Britain's allies, and a series of upbeat essays that combined metahistory and propaganda on the meaning and significance of the war. ${ }^{59}$

Strachey, on the other hand, after a frisson of patriotism in August 1914, was almost as overdetermined by his scepticism to become a pacific bystander and a conscientious objector on non-religious grounds. Convinced that the war was a cock-up not a conspiracy, that it constituted a relapse from cosmopolitan civility into superstition and barbarism and that the real enemies of freedom were conformity, censorship and conscription - that Puritanism was more pernicious than Prussianism - he wrote anti-war essays, dialogues and poems, retired to oases like Garsington where he could enjoy the comforts of prewar civilisation, and turned his appearance before a military tribunal in 1916 into a pacifist farce. In his writings, he argued that self-righteous activism was more likely to bring misery than was self-indulgent harmlessness, that the private pleasures of friendship, love and beauty were preferable to the duties of patriotism, comradeship, honour and self-sacrifice, that the wartime abuse of language and manipulation of literary greats for nationalist purposes was ridiculous, but that militarism like religious intolerance could vanish - that the pen could prove mightier than the sword. And, in Eminent Victorians, he toppled wartime idols. ${ }^{60}$

Eminent Victorians is not simply revisionist biography. It is primarily a polemic, intimately linked to militant pacifism. Under pressure of war, Strachey had reduced the 12 Victorian 'silhouettes', with which he had started in 1913, into a study of just four 'disagreeable' ones. The aim, said Strachey, shortly after the book's publication in May 1918, was 'to make

59 I have examined Trevelyan's wartime experiences and writings at length in MacLachlan, 'Becoming National', 23-44.

60 Lytton Strachey, 'Voltaire and Frederick the Great', Edinburgh Review, 222 (October 1915), 351-73; Strachey, 'King Herod and The Rev. Mr. Malthus', undated but probably late 1914, BL, Add.Ms., 81,892, no. 6 (shorter version in Levy, The Really Interesting Question, 107-10); Strachey, 'Boccaccio and General Lee', 'Sennacherib and Rupert Brooke' (both mid-to-late 1915), BL, Add. Ms., 81,892, nos. 5, 2; Levy, The Really Interesting Question, 40-44; Strachey, 'Militarism and Theology', May 1918, 'Peace and Peace Traps', June 1918, 'The Claims of Patriotism', July 1918: all in War \& Peace, 5 (1918), 249-50, 269-70, 292-3. His most extreme pacifist views can be found in his unpublished 300-line poem, 'Last Night I Dreamt I went to Hell', BL, Add.Ms. 91,908 (unfoliated), written between 1915 and 1922 . 
a protest' against 'a whole set of weaknesses which ha[d] been hitherto either ignored or treated as virtues'. Starting with the worldly ecclesiastic (Cardinal Manning) and moving on to the pitiless humanitarian (Florence Nightingale), the obtuse educationalist (Thomas Arnold) and the maverick crusader (General Gordon), Strachey's portrait gallery anatomised four power-hungry public figures and four instrumental philosophies - religious ambition, self-promoting philanthropy, public school morality and missionary imperialism - that had led Britain into war and deluged it in blood. ${ }^{61}$

Mary Ward accused Strachey of 'literary Prussianism', and her son-in-law - despite his approbation on a first reading - came to agree. ${ }^{62}$ For Strachey placed under the microscope much that Trevy held most dear. While both men might deplore prelatical religiosity and missionary imperialism, for Trevy liberal reformism had not only inspired his prewar writing but also, in the shape of public school chivalry and conscience-salving humanitarian service, had informed his activities during the war. Alongside Manning, the ambitious ecclesiastic, and Gordon, the bible-bashing adventurer, were the great vocational do-gooders of the age: Florence Nightingale and Thomas Arnold. Lytton's Dr Arnold had no obvious redeeming features. All hustle and bustle, bursting with sexual fears, obsessed by 'moral evil', he was an obtuse, sanctimonious humbug, who 'strove to make his pupils Christian gentlemen', but proved only 'the founder of the worship of athletics and ... good form'. Eminent Victorians is an anti-heroic text. Like Trevelyan, the Victorians loved heroes, and with Arnold the pedestal was set particularly high. He, most clearly of all the eminences, was commemorated in one of those pious 'obituary notice[s]' Strachey lambasted in his Preface, Dean Stanley's Life and Correspondence of Dr. Arnold - the work used almost exclusively for his study, and one that he manifestly despised. Chronologically barely a Victorian - born in 1795 he died four years into Victoria's reign - Arnold was the most Victorian of them all: the most

61 Lytton Strachey, Eminent Victorians (EV), ed. John Sutherland (Oxford: Oxford University Press, 2003), xi-xii; Noel Annan provides what is still the best brief introduction to $E V$, in Strachey, EV (London: Collins, 1959), see esp. 9-12; Blanche Athena Clough to S, 1 October 1918, S to Clough, 20 October 1918, BL, Add.Ms., 60,662, ff. 108-10.

62 Mary Ward in TLS, 11 July 1918, in Sutherland, Mrs Humphry Ward, 201; 'Is there a Menace of Literary Prussianism?', Current Opinion, 65 (October 1918), 253-4; 'Literary Shock Tactics', Current Opinion, 65 (July 1918), 182-3; Trevelyan's initial approval probably derived from his avuncular attitude to Strachey, his misjudgment of Strachey's underlying motives, and the fact that he was just returning from front-line carnage. 
earnest, morally embattled, 'disagreeable' - and influential. He disciplined and indoctrinated the Victorians and made them dutiful, pharisaical, conformist, emotionally stunted - and immensely energetic. ${ }^{63}$

Strachey had started his book with Cardinal Manning. It seemed a curious choice, for on the face of it, here was a totally unrepresentative figure: a Catholic Cardinal in an overwhelmingly Protestant country, a revival of 'that long line of ... clerics which ... had come to an end ... with Cardinal Wolsey ... coming to maturity with the first onrush of Liberalism and living long enough to witness the victories of Science and Democracy'. But the choice was deliberate. Begun shortly after a visit to Rome in $1913-$ the Rome of St Pius X, the anti-modernist Catholic warrior - Strachey's Manning was a representative not an aberrant figure: at once a modern figure fighting alongside London dock-workers for social justice and an ambitious, superstitious medieval relic. For all its seeming progressivism and modernity, Victorian England in Strachey's view was fundamentally a credal society, a society of believers, and it had more in common with the thirteenth than with the eighteenth century. ${ }^{64}$

How Manning, the champion of Papal infallibility and defender of the Syllabus Errorum - Rome's denunciation of 'the favourite beliefs of the modern world' - came to be buried as a hero in the world's first modern metropolis, Strachey explored initially through an account of the Oxford Movement. Again, it was no accident that he began his study with the spiritual and theological agonies of the Tractarians. For, as Sir Edmund Gosse explained, the Victorian age proper opened not, as liberal historians had it, in an atmosphere of parliamentary, economic and administrative reform but 'in a tempest of theology'. And the Oxford Movement, 'as might be expected from the place and time of its birth', was 'very remote from modern and secular influences'; indeed, it was the work of superstitious freaks at war with the values of modern, civilised behaviour. Thus described, Strachey's Victorian age was a rupture or a relapse in English history: a religious throw-back or a counter-enlightenment, sandwiched

63 Edmund Gosse, 'The Agony of the Victorian Age', Edinburgh Review, 228 (October 1918), 276-95; John Gardiner, The Victorians, An Age in Retrospect (London: Hambledon Continuum, 2003), 4-5, 131-2; Arthur Penrhyn Stanley, The Life and Correspondence of Thomas Arnold, D.D. (London: B. Fellows, 1845); A.O.J. Cockshut, Truth to Life: The Art of Biography in the Nineteenth Century (London: Collins, 1974), 87-105.

64 Strachey, EV, 9-10; Holroyd, LSNB, 285-6; on Pius X and the 'grim Cardinals', see Leonard Woolf to S, 4 January 1915, in Frederic Spotts, ed., Letters of Leonard Woolf (New York: Harcourt, 1989), 210; on 'Old Catholic' versus 'New National Rome', R.J.B. Bosworth, The Whispering City: Rome and its Histories (New Haven, CT: Yale University Press, 2011), 141-4. 
between one age of secular cosmopolitan enlightenment and what he had hoped, writing early in 1914, would be another. But as 1914-18 showed, 'militarism and theology' were recurring vices: progress in morals and civilisation was an illusion, and history moved in a cycle of flux and reflux, ages of agnosticism and disbelief interspersed with ages of faith, and peaceful progress with war. ${ }^{65}$

'Every war', writes Paul Fussell, 'is ironic because ... its means are so dramatically disproportionate to its ends. But the Great War was more ironic than any before or since. It was a hideous embarrassment to the prevailing meliorist myth ... It reversed the idea of Progress.' Strachey was well attuned to this irony. History for him was continually ironic and disproportionate in its effects - for it was invariably the outcome of chance, circumstance and personality. If there was any meaningful movement to the relationship of past and present, it was not an evolutionary continuum, a benign Whig narrative of progress or of liberalism and reform, but one of generational rupture, a seesaw or a cyclical affair, as David Hume had proposed. Victorian England was a credal society; so was the England of 1917 - the England of Horatio Bottomley, Churchill and Lloyd George. As the war showed, credal societies kill, and Eminent Victorians, which started with the credulous clerics of Oxford, ended amidst the catacombs of Omdurman. Submerged for most of the book, the killing gradually worked its way into its fabric, finally coming out into the open in the last paragraph when the 'future lay with ... Kitchener and his MaximNordenfeldt guns', and in a last bathetic shrug of the shoulders, 'it all ended very happily - in a glorious slaughter of 20,000 Arabs, a vast addition to the British Empire, and a step in the peerage for Sir Evelyn Baring' ${ }^{66}$

If Eminent Victorians was a wartime polemic, pervaded by the vehemence of conscientious objection, Queen Victoria (1921) was clearly a book of peace. It was 'a five act comedy,' Lytton told Leonard Woolf, not a satire. Anatomical dissection made way for 'a more subjective spirit of romance',

65 Strachey, EV, 15-35; Gosse, 'The Agony of the Victorian Age', 278-9; Strachey, 'Militarism and Theology', 249-50. On history as flux and reflux, Lytton Strachey, 'The Eighteenth Century', Nation, (45), 29 May 1929, in BE, 199-202; Strachey, 'Congreve, Collier and Macaulay', 55-7.

66 Paul Fussell, The Great War and Modern Memory (New York/London: Oxford University Press, 1975), 7-8; Strachey, EV, 243. Churchill, Bottomley and Lloyd George feature as Moloch, Beelzebub and Belial in Strachey's 'hellish' anti-war poem. He also wrote a fragment on Churchill in 1921, which formed the basis of E.M. Forster's 1922 Dialogue, 'Our Graves in Gallipoli', All in BL, Add.Ms., 91,908; see also S to John Maynard Keynes, 10 December 1919 (on Keynes's Economic Consequences of the Peace), 5 May 1923 (on Churchill's war memoirs), KC, Keynes Mss, PP 45/316/5, ff. 64, 158. 
and melodramatic exposure for a cadenced narrative, initially whimsical and playful, mildly subversive and malicious at its core, but at the end and in memory, roseate and nostalgic. ${ }^{67}$ Yet if the play of accident is more nuanced, and the breaks between acts less violent, the themes of Eminent Victorians are still visible. For Strachey, it was 'the interplay of circumstance and character that makes up the sum of every human life'. And, as with the story of his eminences, Queen Victoria opened with a series of chance events, starting with the sudden death of the Prince Regent's only child, Princess Charlotte, and followed by the unlikely chance of Victoria's birth. ${ }^{68}$ Ruptures became 'turning points', and the great turning points of the reign were connected with the Prince Consort.

Albert, not Victoria - a responsive but not a creative character - was the true begetter of the Victorian age. Victoria, for Strachey, was not very Victorian - but Albert was. With his arrival in 1840, Lord Melbourne - an eighteenth-century survivor: cynical, civilised, slightly sentimental, 'an autumn rose' - was swept aside. Victoria was transformed from feisty, young Hanoverian queen into staid Victorian 'Hausfrau ... walking ... her children [and] inspecting ... lifestock'. Soon:

The last vestige of the eighteenth century had disappeared; cynicism and subtlety were shrivelled into powder; and duty, industry, morality and domesticity triumphed over them. Even the chairs and tables had assumed in singular responsiveness, the forms of prim solidity. The Victorian age was in full swing. ${ }^{69}$

Albert appears as a kinder version of Dr Arnold, and his attempts to educate and indoctrinate court and government are frustrated by some very un-Victorian characters - by Palmerston, a jaunty Regency throwback, and by Edward VII, a post-Victorian who proved 'strangely resistant' to his father's moral engineering, and grew into something very different,

67 S to Leonard Woolf, 16 December 1919, Berg Collection, Strachey Mss, Strachey-Woolf Letters; TLS, 7 April 1921, 215; Times, 7 April 1921; Nation, (31), 16 April 1921; Clive Bell to S, 'Saturday', April 1921, BL, Add.Ms., 50,559, ff. 126; Dorothy Bussy to S, 17 April 1921, BL, Add. Ms., 60,661, f. 237.

68 Strachey, Queen Victoria, Manuscript Preface (unpublished), HRHC, Strachey Mss, Box 2, folder 7; Lytton Strachey, Queen Victoria (QV) (Harmondsworth: Penguin, 1971; first published 1921), 10-12, 21, 24. See A.N. Wilson, The Victorians (London: Hutchinson, 2002), 24-6 for the much-repeated speculation that Victoria was not the Duke of Kent's daughter; for speculation about Albert's birth, Strachey, QV, 82.

69 Strachey, QV, 54-7, 118. 
at once another George IV and the exemplar of a more modern kingship. ${ }^{70}$ Unlike Arnold, Albert is a tragic as well as a comic figure. The pressure of unrelenting duty, endless activity and constant dissatisfaction destroys his health and brings about his early death, the other great turning point of the reign. Had he lived, Strachey asked in an unusual counterfactual, 'perpetually at the centre of affairs ... virtuous, intelligent ... with the unexampled experience of a whole lifetime of government', would not 'such a ruler', armed with 'the prescriptive authority' of wisdom and age, have 'convert[ed] England into a State as ... organized, as elaborately trained and as autocratically controlled as Prussia herself'? But, as it was, 'what chance gave, chance took away. The Consort perished in his prime; and the English Constitution, dropping the dead limb with hardly a tremor, continued its mysterious life as if it had never been'. ${ }^{71}$

The death of Albert put Victorianism in aspic or black crepe for nearly a generation, as the widowed queen's mawkish grief reached its hideous apotheosis in the Albert Memorial. ${ }^{72}$ But, politically, Victoria lacked the directing intelligence, skill and perseverance to manipulate 'the complex and delicate principles of the Constitution' to the Crown's advantage. Rather, 'the threads of power which Albert had so laboriously collected, fell from her hands into the vigorous grasp of ... Mr. Gladstone, Lord Beaconsfield and Lord Salisbury'. Then, gradually Albert's dead hand loosened and a third Victoria emerged, as the product not of an abrupt transformation but a gradual metamorphosis: a reflection of Albert

70 Strachey, QV, 123-50, 151, 154; on Edward VII, Lytton Strachey, 'A Frock-Coat Portrait of a Great King', Daily Mail, 15 October 1927; Leonard Woolf, 'To See the Kings Go Riding By', Nation, (42), 22 October 1927, 118; David Cannadine, 'The Last Hanoverian Sovereign?: The Victorian Monarchy in Historical Perspective', in A.L. Beier, David Cannadine and James M. Rosenheim, eds, The First Modern Society: Essays in Honour of Lawrence Stone (Cambridge: Cambridge University Press, 1989), 138-9, 158-9.

71 Strachey, $Q V, 147-8,176-8$. Strachey's counterfactual was based largely on Baron Stockmar, Denkwürdigkeiten aus den Papieren des Freiherrn Christian Friedrich von Stockmar (Braunschweig: F. Vieweg und Sohn, 1872) which he read with some difficulty, 'about 1 page an hour'. See $S$ to Dora Carrington, 26 February 1919, BL, Add.Ms., 62,890; Frank Hardie, The Political Influence of Queen Victoria, 1861-1901 (London: Oxford University Press, 1935); Cannadine, 'The Last Hanoverian Sovereign?', 139-46. Cannadine modified his position in 'From Biography to History: Writing the Modern British Monarchy', Historical Research, 77:197 (August 2004), 289-312, doi.org/10.1111/ j.1468-2281.2004.00211.x.

72 Strachey, QV, 190-1; S to Dora Carrington, 21 September 1919, BL, Add.Ms. 62,891; S to Vanessa Bell asking her opinion of the Albert Memorial, 1 March 1919, Robert Taylor Collection, Princeton, Strachey Mss, Letters to Vanessa Bell; Strachey started to lampoon the Albert Memorial very early: in his first Apostle's Paper, he imagined the Prince Consort rising from his seat and standing naked in front of shocked Victorians. 
still, but also of Disraeli, that most un-Victorian of characters. ${ }^{73}$ So, to the last years of her reign, which in their 'solid splendour' seemed, in Strachey's opinion, 'hardly paralleled' in England's history; so also to the iconic figure of the Golden and Diamond Jubilees. Amid the 'established grandeur' of Lord Salisbury's imperial Britain, Victoria had become a fixture, 'a magnificent immovable sideboard in the huge saloon of state'. In many ways, it was an affectionate portrait - half ironic, half-admiring. Trevelyan, who typically missed the subversive undertow and believed that Strachey had come to scoff but stayed to admire, told a friend that the most important event in the history of twentieth-century English biography was 'the conquest of Strachey by Queen Victoria'. To the more committedly anti-Victorian among his Bloomsbury friends, Lytton had lost his passion. 'Carrington and the young men', they thought, had taken the edge off his writing, and changed the claws of Eminent Victorians into the soft-pawed pussy touch of Queen Victoria. ${ }^{74}$

After the war, Trevelyan had expected to go on writing in the same manner as before, returning to the 'world of reform [he] so loved'. But fashion had changed, and the public had no time for his prewar heroes. Commented Harold Laski in 1919, for example, 'I re-read Trevelyan on Italy, and to my astonishment, found a large part of it merely brilliant rhetoric, where ten years ago I remember being swept off my feet by it'. ${ }^{75}$ When Grey of the Reform Bill was eventually published early in 1920, it sold poorly. The writing - literary, rhetorical, respectful, a frock-coat biography with all the proprieties intact - seemed irredeemably Victorian. And Trevelyan's 'dignified aristocrat', whose career 'ennoble[d] the annals of English statecraft', was more of an effigy than a man. In Grey's case, this was especially unfortunate. As a young man, he was overbearing, vain and moody. He had fallen passionately in love with the fashion icon of the age, Georgiana Duchess of Devonshire. Thereafter, even in Fox's louche

73 Strachey, QV, 238-9; Lytton Strachey, 'Dizzy', The Woman's Leader, 12, 16 July 1920, in BE, 264-7.

74 Strachey, QV, 224-5, 240-1; T to S, 6 May 1921, BL, Add.Ms., 60,732, f. 198; Trevelyan, quoted in Charles Richard Sanders, Lytton Strachey: His Mind and Art (London: Oxford University Press, 1957), 227; Leonard Woolf, 'The Biography of Kings', Nation, (36), 21 March 1925, 859; Anne Bell and Andrew McNeillie, eds, The Diary of Virginia Woolf, Volume III (London: Hogarth Press 1980), 28 November 1928, 208-9.

75 Cannadine Trevelyan, 15, 101-4; Moorman, George Macaulay Trevelyan, 129; T to G.O. Trevelyan, 1 April 1919, PRL, Trevelyan Mss, GOT 107; Harold Laski to Oliver Wendell Holmes, 14 December 1920, quoted in Feske, From Belloc to Churchill, 167. 
circle, he had a reputation, and his affairs continued well into his 70s. None of this made its way into Trevelyan's biography, which was written well within the 'Great Wall of Victorian respectability'. ${ }^{76}$

Absent from Trevelyan's work were precisely the features that concerned Strachey: the play of personality, the texture of a life, psychic interiority in all its contradictions, rather than the spurious coherence retrospectively given to a public career. Also missing were the qualities Lytton had made fashionable, enabling him to strip away the Victorian varnish from political biography: irreverence, a probing imagination, a sense of irony, ambiguity and paradox. With all their talk of liberty, democracy, reform and free trade, Trevelyan's ancestral Whig heroes had become derided Eminent Victorians - or, as Leonard Woolf put it when John Bright was reissued in 1927, 'antediluvians and patriarchs'. So Trevelyan backed off. His need for heroes never entirely dissipated, but they were now heroes in eclipse: not Garibaldi the heroic national unifier, but Manin, the noble republican failure; not Lord Grey of reform, but Edward Grey, the man of good intentions who was powerless as the lamps went out. The heroes of the Risorgimento or English Liberalism were always shaping or imposing themselves on events; now they could only respond to or flee from them. In the dialectic between predestination and free will, Trevelyan, once the champion of moral choice and free action, moved towards determinism. ${ }^{77}$

Perhaps then, it was better to avoid biography. So the focus of Trevy's writing altered, as did its tone and texture. British History in the Nineteenth Century (1922) coincided chronologically with his work on Bright and Lord Grey, but it could hardly have been more different. This was a book shorn of rhetoric and imaginative colour, lacking obvious artistic form. It was impersonal, undramatic, dry - almost 'dry-as-dust' - without heroes or villains, or with plaudits so widely and evenly spread as to be virtually neutral. Pitt and Fox, Grey and Canning, Melbourne and Peel, Aberdeen and Palmerston, Gladstone and Disraeli were all well-meaning men of principle and courage who 'in the main wrought greatly and beneficently'.

76 G.M. Trevelyan, Lord Grey of the Reform Bill, passim; one reviewer complained that Grey was 'morally ... about ten foot tall', Nation, (27), 26 March 1920, 159; TLS, 25 March 1920. For the skeletons in Lord Grey's cupboard: Amanda Foreman, Georgiana: Duchess of Devonshire (London: HarperCollins, 1998). The Duchess, the movie of 2008, presents a very different Charles Grey; see www.imdb.com/title/tt0864761/ (accessed 8 October 2016).

77 Leonard Woolf, 'John Bright and Liberalism', in Woolf, Essays in History, Literature, Politics, Etc. (London: Hogarth Press, 1927), 218-22; G.M. Trevelyan, Manin and the Venetian Revolution of 1848 (London: Longmans, Green, 1924); Trevelyan, Grey of Fallodon (London: Longmans, Green, 1937). 
Thus described, modern British political history embodied the philosophy both of Burke and Bentham: the 'conservative principles which constitute one half of our social happiness', and 'the spirit of liberalism ... never neglected without disaster'. Historical change was brought about not by the triumph of progressive heroes, but through the interplay of reformers and stabilisers - 'the two party system'. Trevelyan had once written that genuine wisdom 'does not always consist in sympathy and tolerance. The world is moved in the first instance by those who see one side of a question only'. Now, he believed it was the consensualists who were the wisest: 'no one party could cover all the ground'. ${ }^{78}$

He still saw the nineteenth century - which he opened in 1782 on the eve of reform - in evolutionary, liberal terms. Whereas Strachey's Victorian age was saturated in theology, his was a secular, improving society. Indeed, coming after Strachey's corrosive anatomy, Trevelyan's, for all its spiritual anaemia and industrial ugliness, was upbeat and reassuring. But it was an academic rather than a literary portrait. Strachey and his literary imitators viewed Trevelyan's history as a 'tiresome' Victorian relic. Trevy, for his part, was convinced that 'Lytton had poisoned history, traduced the Victorians and created a fashion for cheap ... nasty ... one volume biographies, designed to meet the demand for sensational literature. ${ }^{79}$ Just how far the rot had gone - how far standards were set by the 'suave practitioners of denigration' - was illustrated in 1923 by the fate of a book dedicated to Trevelyan, F.A. Simpson's Louis Napoleon. Simpson was a scrupulous literary historian in the Trevelyan mould - a Trinity don who, thanks to Trevy, had landed the life Fellowship that passed Lytton by. But his publishing career was abruptly terminated by a destructive anonymous review in the Times Literary Supplement:

History (there is no use denying it) is mainly about dead people. But it is the duty of historians to convince us that they were once alive ... Mr Simpson's ... grave narrative disdain[s] the bright colours, the quick, undignified movement of reality, without [which] one may write sound history but never get [the past] to live.

78 G.M. Trevelyan, British History in the Nineteenth Century (1782-1901) (London: Longmans, Green, 1922); Cannadine, Trevelyan, 107-9, 120-1; Trevelyan, England in the Age of Wycliffe, 181; Trevelyan, 'The Latest View of History', 412; G.M. Trevelyan, The Two-Party System in English Political History (Oxford: Clarendon Press, 1926); Feske, Belloc to Churchill, 175-8.

79 Cannadine, Trevelyan, 44. 
Trevelyan was outraged: the Strachey-esque comments were a call for a history that was all sail but no ballast, all 'personality and pageant' but no politics, 'unimaginable in a serious study'. ${ }^{80}$ Convinced that the popularity of the new biography had led to a decline in the art of writing history and that the old alliance between freelance literary history and progressive politics had broken down, he returned to the academy. Keen to avail himself of 'the aura of authority' that a senior academic position might confer, he succeeded Bury as Regius Professor of History at Cambridge in 1928 - the culmination of a fence-building exercise going back many years. ${ }^{81}$

Yet he had not abandoned the pursuit of popular literary history. His tactics may have changed; the goal remained the same. Despite his formal academic position, he still believed 'the appeal of history ... [wa]s in the last analysis poetic', and he saw himself as the heir of Walter Scott, Macaulay and Carlyle, rather than as Bury's spiritual successor. ${ }^{82}$ He was delighted when Strachey abandoned critical Victorian biography to devote himself to a romantic evocation of Elizabethan court society, in what he believed was his 'greatest work', his Elizabeth and Essex: 'not a piece of satire but a piece of life'. So much the more was he appalled when Strachey returned to his most satirical manner in his last published set of essays, Portraits in Miniature, especially as the most deflating pieces were on the Trevelyan family icons, Macaulay and Carlyle. ${ }^{83}$ By the time Strachey died in 1932, it was clear that generational and temperamental differences, exacerbated by the war and by their increasingly divergent postwar lifestyles, friendships, tastes and judgements as to the role of biography and history had turned to mutual antipathy. To Strachey's Bloomsbury friends, 'Old Trevy' was now 'the complete insider ... the

80 Philip Guedalla, review of Louis Napoleon and the Recovery of France, $1848-1856$ by F.A. Simpson, TLS, 25 January 1923, 55; G.M. Trevelyan, 'The Writing of History', TLS, letters, 1 February 1923, 76; Guedalla, 'The Writing of History', TLS, letters, 8 February 1923, 92; Strachey in fact hated Guedalla's writing, which he saw as a crude parody of his own: Carrington, file of correspondence to Noel Carrington, Tate Gallery Mss, TGA 797/2/22, 7 August 1922.

81 Feske, Belloc to Churchill, 151-5, offers the best analysis of Trevelyan's retreat to academe; G.M. Trevelyan, 'History and Literature', History, 9 (1924), 81-91, doi.org/10.1111/j.1468-229X.1924. tb00409.x; Leonard Woolf, 'The New Art of Biography', Nation, (38), 12 December 1925, 404; A.F. Pollard, 'The Progess of History', TLS, 26 June 1930, 521-2.

82 Trevelyan, 'The Present Position of History', 106; Cannadine, Trevelyan, 196, 159-60; G.M. Trevelyan, 'Walter Scott: The Novelist as Historian', The Times, 21 September 1932.

83 T to S, 28 November 1928, BL, Add.Ms., 60,732, ff. 200-1; Lytton Strachey, Portraits in Miniature (London: Chatto \& Windus, 1931), which included 'Six Historians': Hume, Gibbon, Macaulay, Carlyle, Froude and Creighton; for Virginia Woolf on Trevelyan's reaction, see $S$ to Roger Senhouse, 30 December 1930, Berg, Strachey Mss, Strachey-Senhouse Letters; Holroyd, LSNB, 653. 
perfect product of the university machine'. To Trevelyan and his fellow dons, Strachey was an irritating gadfly - and a supercilious intellectual. 'As to intellectuals,' Trevy told his daughter in 1942, 'one of the greatest disappointments of my life has been the decadence of that class (if you can call it a class), of which I first became aware when Lytton Strachey came up to Cambridge. ${ }^{84}$

Historical texts, like other literary artefacts, carry their own internal imperatives. And it is possible that comparative biography - especially when it tries to highlight temperamental and generational differences - may explain too much, thereby rendering writings textually undernourished and biographically 'overdetermined'. As Strachey once put it, quoting Mallarmé, 'poetry is not written with ideas, it is written with words': 'these things that we have made are as much alive as we are, and we have become their slaves' ${ }^{85}$ Yet it is difficult to believe that Strachey and Trevelyan were so enslaved; for history is written with ideas and philosophies as well as with words. And their families, backgrounds, lifestyles, assumptions, moments and milieus were not irrelevant to their choice of subjects and to their treatment of them. As such, biography may help to elucidate the sources of their early friendship and the growing antipathy between them. Clio, like all the muses, speaks in tongues, and examining Clio's historians surely helps us to decipher them. ${ }^{86}$

84 For Trevelyan on Virginia Woolf, see Cannadine, Trevelyan, 39, 255; T to Mary Moorman, 10 April 1941, PRL, Trevelyan Mss, MM 1/4/29; Anne Bell and Andrew McNeillie, eds, The Diary of Virginia Woolf, Volume IV (London: Hogarth Press, 1982), 24 August 1933, 174; Bell and McNeillie, eds, The Diary of Virginia Woolf, Volume V (London: Hogarth Press, 1984), 26 October, 5 November 1940, 333, 337; Feske, Belloc to Churchill, 152-3; T to Mary Moorman, 30 June 1942, PRL, Trevelyan Mss, MM 1/4/30.

85 Lytton Strachey, Introduction to George H.W. Rylands, Words and Poetry (London: Hogarth Press, 1928), in $L E, 16-19$; Strachey, 'Peace and Peace Traps', 269-70.

86 Trevelyan, Clio, A Muse and Other Essays. 
This text is taken from Clio's Lives: Biographies and Autobiographies of Historians, edited by Doug Munro and John G. Reid, published 2017 by ANU Press, The Australian National University, Canberra, Australia.

dx.doi.org/10.22459/CL.10.2017.07 